\title{
XLIX. Abstract of the histroy of a new class of platina-salts, discovered by M. Gros, with some remarks on their true constitution
}

\section{Robert Kane M.D. M.R.I.A.}

To cite this article: Robert Kane M.D. M.R.I.A. (1841) XLIX. Abstract of the histroy of a new class of platina-salts, discovered by M. Gros, with some remarks on their true constitution , Philosophical Magazine Series 3, 18:117, 293-296, DOI: 10.1080/14786444108650297

To link to this article: http://dx.doi.org/10.1080/14786444108650297

曲 Published online: 01 Jun 2009.

Submit your article to this journal $\pi$

ЏII Article views: 2

Q View related articles $₫$ 
The composition and mode of formation of elaidic acid was undertaken, as his task, by Dr. Meyer. The accurate examination of coccostearic acid (coccinic acid), as well as of the products which originate from the action of nitric acid on fat bodies, was undertaken by M. Bromeis : the composition of the margaric acid in palm oil, and of the acid in cacao butter, by Mr. Stenhouse of Gilasgow; on the composition of the fat substances of the nutmeg butter, and of the wax, by Mr. Playfair of Calcutta*.

[To be continued.]

XLIX. Abstract of the History of a new class of Platinasalts, discovered by M. Gros, with some Remarks on their true Constitution. By Robert Kane, M.D., M.R.I.A. $\dagger$

THE very singular substance discovered by Magnus, and 1 formed by boiling protochloride of platina in water of ammonia, is well known to consist of $\mathrm{Pt} \mathrm{Cl}+\mathrm{NH}_{3}$. By this direct process it is formed but slowly and in small quantity, and a better mode of obtaining it was invented by Liebig. A solution of perchloride of platina is treated by a current of sulphurous acid gas, until the liquor becomes deep reddish brown, and ceases to precipitate a solution of sal-ammoniac. Being now brought to boil, and water of ammonia being added, Magnus's salt precipitates in fine deep green silky needles. In this way Gros obtained it in quantity sufficient for his researches.

When this substance is treated with warm nitric acid it (the acid) becomes brown, and finally converts the salt into a white powder. Red fumes are given off, and generally some double perchloride of platina and ammonium produced, and some metallic platina separated. The white salt is obtained pure by solution in warm water, from which it crystallizes on cooling. This salt is colourless, and in brilliant flat prisms. Heated with caustic potash it evolves ammonia, but not otherwise. It is not precipitated by sulphuretted hydrogen. On analysis it yields $\mathrm{Pt} \mathrm{Cl} \mathrm{N}_{3} \mathrm{H}_{6} \mathrm{O}_{6}$.

* [The authors had subjoined to this notice of the recent investigations respecting the fatty bodies, particulars of some of their results; but as several of the memoirs containing them have now appeared entire in our pages, together with an abstract of others, we deem it best to add merely the following references:-An abstract of the researches on the fatty substances by Redtenbacher, Varrentrapp, Meyer and Bromeis, was given in the Number for February, pres. vol., p. 113, preceded, at p. 102, by Dr. L. Playfair's paper on a new fat acid in the butter of nutmegs; and in our last number, p. 186, appears Mr. Stenhouse's memoir on palm oil and cacao butter.-Enir.]

+ See p. 284. of the present Number. 
When a solution of this salt is treated with sulphate of soda, a new compound separates in needles. This is also obtained by decomposing the first salt by dilute sulphuric acid, nitric acid being expelled. A solution of this salt yields no precipitate with nitrate of barytes, but gives sulphate of barytes when an excess of nitric or muriatic acid is added. Its analysis gives the formula $\mathrm{Pt} \mathrm{Cl} \mathrm{N}_{2} \mathrm{H}_{6} \mathrm{~S} \mathrm{O}_{4}$.

On mixing a warm solution of the nitric acid salt with oxalic acid, a white powder, insoluble in water, is thrown down, which has the composition $\mathrm{Pt} \mathrm{Cl} \mathrm{N}_{2} \mathrm{H}_{6} \mathrm{C}_{2} \mathrm{O}_{4}$.

With a solution of common salt another compound is generated, the composition of which is $\mathrm{Pt}_{2} \mathrm{Cl}_{2} \mathrm{H}_{6}$.

When we compare the above formula with one another, we observe that there is common to all, the elements of an atom of protochloride of platina, one of amidogene and one of ammonium, $\mathrm{Pt} \mathrm{Cl}+\mathrm{N} \mathrm{H}_{2}+\mathrm{N} \mathrm{H}_{4}$, and that the changeable element is such, as to form, with the ammonium, an ordinary ammoniacal salt. The simplest rational formula which could be devised for them, should therefore be to look upon the platina as having been raised to the state of percombination by the nitric acid, a chloramide being formed, $\mathrm{Pt}+\mathrm{Cl} \mathrm{NH}$, resembling the bichloride, an atom of chlorine being replaced by amidogene, as an atom of oxygen may be replaced in chromic acid by chlorine. Then the formulæ of Gros's salts become

$$
\begin{aligned}
& \text { 1. }(\mathrm{Pt}+\mathrm{Cl} \cdot \mathrm{Ad})+\left(\mathrm{Am} \cdot \mathrm{O}+\mathrm{NO}_{5}\right) \\
& \text { 2. }(\mathrm{Pt}+\mathrm{Cl} \cdot \mathrm{Ad})+\left(\mathrm{Am} \cdot \mathrm{O}+\mathrm{SO}_{3}\right) \\
& \text { 3. }(\mathrm{Pt}+\mathrm{Cl} \cdot \mathrm{Ad})+\left(\mathrm{Am} \cdot \mathrm{O}+\mathrm{C}_{2} \mathrm{O}_{3}\right) \\
& \text { 4. }(\mathrm{Pt}+\mathrm{Cl} \cdot \mathrm{Ad})+(\mathrm{Am} \cdot \mathrm{Cl})
\end{aligned}
$$

MM. Gros and Liebig reject this view on the following grounds : 1st, that the difficulty which is found in expelling the ammonia from these compounds excludes the idea of the presence of an ordinary ammoniacal salt; and 2nd, that the sulphuric acid compound not immediately precipitating a salt of barytes, shows that common sulphate of ammonia does not exist therein. Gros therefore considers that the platina, chlorine, nitrogen, and hydrogen are all united together in a compound radical, which in No. 4. is united to chlorine, and in the others with oxygen and an acid. Thus, $\mathrm{Pt} \mathrm{Cl}$ $\mathrm{N}_{2} \mathrm{H}_{6}=\mathrm{X}$ we have,

1. $\mathrm{Pt} \mathrm{Cl} \mathrm{N} \mathrm{H}_{6} \mathrm{O}_{6}=\mathrm{X} \cdot \mathrm{O}+\mathrm{NO}_{5}$.

2. $\mathrm{PtCl} \mathrm{N} \mathrm{H}_{6} \mathrm{SO}_{4}=\mathrm{X} . \mathrm{O}+\mathrm{SO}_{3}$.

3. $\mathrm{Pt} \mathrm{Cl} \mathrm{N} \mathrm{N}_{6} \mathrm{C}_{2} \mathrm{O}_{4}=\mathrm{X} . \mathrm{O}+\mathrm{C}_{2} \mathrm{O}_{3}$.

4. $\mathrm{Pt} \mathrm{Cl}_{2} \mathrm{~N}_{2} \mathrm{H}_{6}=\mathrm{X} . \mathrm{Cl}$.

Liebig endeavours to establish a relation between this compound radical and ammonium, by proposing to consider the 
radical to consist only of $\mathrm{Pt} \mathrm{Cl} \mathrm{N}_{2} \mathrm{H}_{2}$; that this fulfils a function like that of azote, and combining with $\mathrm{H}_{3}$ forms the true basis, which is associated in Gros's salts with hydrated acids or with chloride of hydrogen.

In this confused state of our knowledge of so interesting a class of bodies, I think it right to publish some facts with regard to their origin and constitution which $I$ had discovered a long time ago; for after having completed my researches on the mercurial compounds formed by ammonia, I commenced the analogous examination of the platinum bodies, and had formed many new substances, among others the muriatic and oxalic salts of Gros, when his memoir appeared. I then thought that he would pursue the subject further, but as it would be useless for two persons to be losing time doing the same thing, and I thought that he was ahead of me in time, I laid the subject aside, and passed to other matters. I have lately resumed that investigation, and combining my old results with those which I since obtained, I consider that the nature of those boulies may be now explained.

I formed these salts originally, not as M. Gros did, from Magnus's salt, but by acting with ammonia on the perchloride of platina. There are produced a series of bodies, which it is not my object to describe here, but ultimately a colourless solution, which gives with alcohol a white precipitate, which is the basis of Gros's salts, that he had endeavoured in vain to isolate. Its composition is $\mathrm{Pt} \mathrm{Cl} \mathrm{N}_{2} \mathrm{H}_{6} \mathrm{O}+2 \mathrm{Aq}$. Its solution in water gives with acids all Gros's salts. Now in its formation the series of decompositions from the perchloride $\mathrm{Pt} \mathrm{Cl}_{2}$ is fully developed. And it is important also that by passing an excess of dry gaseous ammonia over perchloride of platina, Gros's muriate is produced, for its constitution may be represented as $\mathrm{Pt} \mathrm{Cl}_{2}+2 \mathrm{~N} \mathrm{H}_{3}$. It is evident, therefore, that these complex bodies are deduced from the perchloride of platina just as the complex mercurial amides are formed from corrosive sublimate, and as the ammoniacal sulphates, \&c. of silver, zinc, copper, \&c. are produced by an excess of ammonia on the simple salts. But the platinum is remarkable for involving together the types of both the mercurial and copper ammoniacal compounds, and hence rising to a still greater complexity of constitution. Thus in place of $\mathrm{Hg} \mathrm{Cl}+\mathrm{Hg} \mathrm{Ad}$ and $\mathrm{HgI}+2 \mathrm{HgO}+\mathrm{Hg} \mathrm{Ad}$, there are in the platinum series $\mathrm{Pt} \mathrm{Cl}_{2}+3 \mathrm{Pt} \mathbf{A d}_{2}+4 \mathrm{Aq}$, and $\mathrm{Pt} . \mathrm{I}_{2}+\mathrm{Pt} \mathrm{Ad}_{\mathrm{t}}+4 \mathrm{Aq}$. In combination there is, however, $\mathrm{Pt} \mathrm{Cl}_{2}+\mathrm{Pt} \mathbf{A d}_{2}$, and it is this which exists in Gros's salts combined with the common salt of ammonia. From these circumstances, I consider that we have good grounds for 
looking upon Gros's salts, the sulphate for example, as containing the bichloramide of platina united with two equivalents of sulphate of ammonia $\left(\mathrm{Pt} \mathrm{Cl}_{2}+\mathrm{Pt} \mathrm{Ad}_{2}\right)+2\left(\mathrm{NH}_{4}\right.$. $\left.\mathrm{O}+\mathrm{S} \mathrm{O}_{3}\right) . \quad \Lambda \mathrm{s}$ to the objection made by Gros to the existence of common sulphate of ammonia, that neither the acid nor the base can be directly detected, it is well remarked by Berzelius that the view taken by Gros does not in the slightest degree render it easier of explanation. We find, however, many analogous cases. Thus in the double oxalate of chrome and potash, a very trifling quantity of the oxalic acid is shown on the addition of a salt of lime.

I consider that it is not calculated to advance science, when, in order to avoid difficulties in the rational explanation of the constitution and properties of any substance, the theory of organic radicals is employed as unreservedly as it appears now to be by many chemists. It gives an air of simplicity to reactions, very attractive at first sight, and very convenient for explanation, but which, by making us satisfied by surface resemblance or plausibility, may retard important investigations. If, in accordance with Gros's ideas, we make $\mathrm{Pt} \mathrm{Cl} \mathrm{N}_{2} \mathrm{H}_{6}=\mathrm{X}$, the question still remains, what is the structure of $\mathrm{X}$ ? And that question should never be lost sight of. But the substance described by Reiset as the radical of Gros's salts*, and which has indeed the formula of it $\left(\mathrm{Pt} \mathrm{Cl} \mathrm{N}_{2} \mathrm{H}_{6}\right)$, is not so constituted; it is not at all of the series of the bichloride of platina, to which Gros's salts belong, but to the protochloride, being $\mathrm{Pt} \mathrm{Cl}+2 \mathrm{NH}_{3}$, whilst Magnus's salt is $\mathrm{Pt} \mathrm{Cl}+\mathrm{NH}_{3}$. This is evident from the way it is made.

L. Some Remarks on Messrs. Francis and Croft's Abstracts from the Foreign Journals. By A Correspondent. Sir,

$\mathrm{T}^{\mathrm{T}} \mathrm{T}$ has lately been the fashion, especially among those who 1 have spent some time under the great teachers on the continent, to declaim much against the backward state of chemistry in England, and to censure its cultivators in this country for their tardy reception of the new doctrines and new facts continually emanating from the fertile inventions and laborious investigations of their continental brethren.

Perhaps, to a certain extent, the charge may be well founded, and thanks are due to Messrs. Francis and Croft for their laudable endeavours to remove this opprobrium.

On reading their abstracts from the foreign journals inserted

* Francis and Croft's Abstracts, p. 284. 